\title{
Investing in Networking Competences or Establishing in Hot Spots? The Innovation Dilemna
}

\author{
Caroline Hussler', Patrick Rondé ${ }^{2}$
}

\begin{abstract}
The target of this paper is twofold: investigating open innovation practices that are used up in French manufacturing industries, and evaluating the impact on firms' innovativeness of those networking abilities in comparison to internal development of competences and to spillovers available in the neighborhood. Concretely, thanks to a huge database on competences for innovation, the paper estimates the impact of different categories of innovative competences (mostly relational ones) on innovative performance. This empirical analysis first shows that if networking abilities are the core innovative competences, strategies to tap into external innovation sources vary across sectors. Second, this work allows to precise the relational competences that firms should develop in order to improve their innovative performance.
\end{abstract}

Keywords: innovation; networking competences; spillovers.

\footnotetext{
${ }^{1}$ RECITS, Université de Technologie de Belfort-Montbéliard, 90010 Belfort Cedex, France. Tél : ++33 368852 I8I, Fax : ++33 368852 069. Email: caroline.hussler@utbm.fr

${ }^{2}$ GRAICO, Université de Haute Alsace, 68093 Mulhouse Cedex, France, Email: patrick.ronde@uha.fr
} 


\section{Introduction}

If according to location choice models, agglomeration around knowledge creators and absorption of the knowledge which spills over thanks to high levels of absorptive capacities is a key strategy for firms to innovate, a growing strand of research on "regional innovation system" (Cooke, et al., 2004), "learning region" (Maillat and Kebir, 1999) or "open innovation" (Chesbrough, 2003) suggests that what really matters to innovate is the capacity to run cooperative relationships and to be integrated into a dynamic network of (local or regional) inventive actors. Hence organizations do not only need to open up their innovative processes to ideas floating in the ambient air. They also have to work towards building and managing a riche set of active network connections and relationships so as to be able to draw on research and development that may lie outside their boundaries.

If interesting, most of this recent literature on innovation sounds nevertheless unable to "distinguish between benefits associated with social interaction effects within the geographical unit of observation, and agglomeration economies" (Bell, 2005), each effect being however the consequence of completely different strategies. Trying to fill this theoretical blank, Bell (2005)'s empirical attempt to disentangle the respective effects on innovation of, on the one hand, Marshall's business atmosphere and, on the other hand, network ties leads him to conclude that settling down within a cluster enhances firm innovativeness "even after separately accounting for the influence of the network structure" (Marshall, 1890). Indeed, location's surroundings influence the more or less easy access to innovative resources and infrastructures (such as top universities, efficient banking systems, or skilled workforce) whatever the intensity of firms' networking activities. Finally, the environment firms are established in and interactions firms are taking part both seem to drive innovative performance through different mechanisms.

However, and contrasting with those collective and externally-oriented views on innovation, recent articles (among which Oerlemans, et al., 1998; Fritsch, 2004; Love and Roper, 200I) lessen the catalytic role of interorganizational links for the innovative process, their empirical findings concluding that the major part of innovation still stems from firms' internal competences in most industries, as formerly suggested by the linear model of innovation.

The present paper precisely aims at empirically confronting those conflicting/complementary theoretical explanations of the determinants of innovative performances, with the ultimate goal to a) sketch the business model(s) developed by firms to innovate (connecting internal and external sources of innovation?), and b) identify the core competences (Prahalad and Hamel, 1990) firms should develop to become more innovative.

To do so, the first step lies in specifying the networking strategies that are adopted to increase innovation, with the ultimate ambition to make suggestions and help firms to find and form the relevant and most efficient connections (Tidd, 2007). More precisely, if the management of a firm's innovation network becomes a critical task to achieve competitive advantage (Ritter and Gemünden, 2003), most of the papers on the topic concentrate on the need for networking, and neglect to precise the specific networking abilities that have to be built. The present paper aims at highlighting the identity and nature of partners a firm should prioritize to work with by developing adequate competences. Indeed, according to Gemünden, Ritter and Heydebreck (1996) each innovation partner might bring a specific contribution, and therefore firms should master different degrees of network competence with each category of partner. Thus the present contribution builds upon a model simultaneously accounting for multiple networks and exploring the types of open innovation practices that are relevant for innovation. De Jong, Vanhaverbeke and Van de Vrande (2007) already investigate open innovation practices in small firms but with the deliberate objective to identify specificities with regards to the behaviors of large firms. Here the stress is put on differences in open innovation practices between sectors of activity, with the ultimate goal to delineate the key relational competences for innovation in different sectors.

As the business atmosphere might also play a role, the second step of this study consists in comparing the impact of networking strategy to the influence of the resources and spillovers accessible in a given location. In the remainder of the paper a hot spot is defined as a location well endowed in terms of innovative resources but also 
offering access to lots of spillovers stemming from other active firms on the territory. The final aim of the paper is thus to find which of the characteristics of those hot spots really matter to generate the common innovative good that Marshall qualified years ago as "the business atmosphere".

Finally, this contribution measures the impact of open innovation competences developed by regional firms on regional innovative level, and compares those influence to the one generated by the assets of a given location. Concretely, the estimated production function evaluates the impact of competences mastered by firms of a given sector and a given region, on the innovative activity of this sector and this region, but also on the innovative level in neighboring sectors of the region. This modeling is applied in two steps: first, all sectors being included; second, distinguishing between industries.

The empirical results show that competences related to external interactions have a more important impact on innovation than internal innovative competences. Second, unintended knowledge flows (spillovers) accessible in hot spots have less influence on innovation than deliberate flows generated by active networking activities. Hence, the innovative process proves collective, open and interactive in French manufacturing industries supporting strategies dedicated to strengthen networks of actors. Nevertheless, networks of technologically far but geographically proximate activities is of limited interest to enhance innovation. Managers thus have to be selective when building relational capacities.

The remainder of the paper is organized as follows. Section 2 formally presents the econometric model and describes the data and variables. Section 3 reports the results. Section 4 sums up the major conclusions of the study insisting on their interest for the development of appropriate managerial skills.

\section{Econometric specifications}

\section{The model}

In order to identify the competences which are significant for innovation, a "knowledge production function" (Griliches, 1979) in which indicators of competences are the main explanatory variables is estimated. More precisely in this modeling innovativeness is as a function of competences held by regional firms on the one hand and regional innovative potentialities (whether or not the region at stake can be considered as a hot spot) on the other hand.

\section{Measuring innovation}

Patents - actually European patent applications, which involve at least one French inventor- are the indicators selected to proxy innovation. They suffer from a lot of limitations in measuring the innovative output (for a summary, see Griliches (1990), but Acs, Anselin and Varga (2002) recently show that "patents provide a fairly reliable measure of innovative activity". Moreover, patents permit to work on standardized regional data, as the information on innovation is collected in the same way in each region.

A patent is assigned to region $i$, if its inventor has a private address in region $i$. In case of co-inventors (located in different regions), a fraction of patent is attributed to each of the inventors' region, in proportion of the number of inventors located in each region. The region coincides with NUTS 3 level of analysis (i.e. 94 observations) mainly because NUTS 2 level only offers 21 observations, weakening therefore the reliability of any statistical analysis at this second level of aggregation.

A patent is assigned to a given industry according to a matrix of concordance between the 14 industrial sectors available in the database on competences, and the 4-digit international patent classification. This matrix builds upon the one developed by Breschi, et al. (2003).

\section{Measuring networking competences}

To get an idea of the competences required to tap into internal and external sources of innovation, data gathered by the SESSI (a research department of the French Ministry of Industry) on competences for innovation held by 387 I manufacturing companies (with more than 20 employees) located in France sound promising. Indeed, surveyed firms belong to 14 different industries (namely clothing and leather, printing, publishing and reproduction, pharmaceuticals and cosmetics, household appliances, car industry, shipbuilding, aeronautics and railway building, mechanical equipment, electric and electronic equipment, mineral products, textile, wood and paper, chemical industry and plastics, metallurgy and metal working and electric and electronic compounds) and are representative, 
in size and activity, of the 22,000 French manufacturing firms. This questionnaire survey of managers asks them about the mastery, at the firm level, of about 73 elementary competences (for more details about the methodology of the SESSI questionnaire see François, et al., 1999). The term competence is here used to describe skills or knowledge necessary to perform certain tasks without considering the actual execution of the task, as it is the case in Ritter and Gemünden (2003).

Those 73 elementary competences are aggregated into 7 broader competences reflecting firms' main strategies for innovation. Two main strategies are considered: either firms dedicate their energy to develop internal capabilities for innovation, or they devote their time to take advantage of ideas and pieces of knowledge generated by external partners. In the first case, firms might rely on two types of internal innovative competences: "technical competences" and "organizational competences". In the second case, according to Pavitt (1998)'s ideas, five categories of "relational" competences -reflecting capacities to interact with external innovative partners- might be useful, namely competences to develop relations with public institutions, with competitors, with suppliers, with customers and with financers. Appendix I sketches those seven categories of aggregated competences.

To calculate the regional level of each type of competences the number of competences of each category held by firms located in the region is computed. As the number of firms and then the number of competences might significantly differ across regions and thus generate spatial heterogeneity biases, the variable POP (population of each region in thousands of inhabitants) is included in the regression to control for the size of regions.

\section{Evaluating the potentialities for a given location to be considered as a hot spot}

The stock of regional knowledge is a potential explanatory variable of regional innovative dynamism through knowledge spillover mechanisms. Therefore the variables HK which accounts for the percentage of the population devoted to private research is included in the model. In addition to this indicator of human capital level, a second explanatory variable (SD) is introduced. It depicts the productivity of regional universities, as the proximity of top universities and scientific knowledge tends to be determinant in the performance of certain types of research activities. Concretely, the OST data on the number of regional scientific publications per capita in 1997 is used to account for the presence of top universities in a region. The SD variable then scores $I$ if the number of scientific publications per capita in a given region is above the French average, and scores 0 otherwise.

The effect of pecuniary spillovers is also evaluated. Indeed, the present paper investigates the relation between the innovative output of a group of firms (s) in a given region and the competences for innovation mastered by this group of firms (s) but also by firms from the same region active in other sectors. Actually, the empirical analysis concentrates on intra-regional spillovers and examines the impact of regional technological neighbors $(\mathrm{v}(\mathrm{s}))$ and the impact of regional but technologically more distant firms $(w(s))$. Inter-regional spillovers are purposely not addressed here, as they are already well studied for France (Autant-Bernard, 200I), and as Rondé and Hussler (2005, p. 1 164) empirically demonstrate that "competences held by industrial neighbours within a region have more impact [on innovation] than those developed by geographical neighbours involved in the same industrial sector".

To capture the technological similarity/dissimilarity of firms, and build the technological neighborhoods, the procedure developed by Engelsman and van Raan (1992) and applied by Breschi et al. (2003), which analyses the cooccurrences of technological classes in patent documents, is mobilized: the more two fields relatively co-occur in patents, the higher their cosine index and their technological proximity. Finally, sectors which reach a cosine index higher than 0.25 with one another are considered as technological neighbors, whereas others sectors belong to the $w(s)$ set (see appendix 2).

To sum up, the following modified Cobb Douglas model is estimated: 


$$
\begin{aligned}
& \ln I_{i s}=\alpha+\sum_{k=1}^{k=7} \beta_{k} \ln \operatorname{comp}_{k i s}+\sum_{k=1}^{k=7} \delta_{k} \ln \operatorname{comp}_{k i v(s)}+\sum_{k=1}^{k=7} \chi_{k} \ln \operatorname{comp}_{k i w(s)} \\
& +\beta_{m} \ln \operatorname{pop}_{i}+\beta_{n} S D_{i}+\beta_{p} \ln R D_{i}+\beta_{r} \ln H K_{i}+u_{i s}
\end{aligned}
$$

where I stands for the level of innovation, comp is the number of competences, pop refers to the population of the territory, $S D$ is a dummy variable accounting for the presence of a top-ranking university, $R D$ measures $R \& D$ expenditures, HK refers to the percentage of population devoted to R\&D, $i$ indexes the geographic units of observations, $k$ indexes the category of competences (see appendix I), s indexes the 14 technological industries, $v(s)$ refers to the set of sth proximate technological areas, w(s) refers to the set of sth "non neighboring" technologies (see appendix 2 for details) and $u_{i s}$ is the error term.

Last point to be noticed, all explanatory variables refer to the year 1997 and are used to explain the innovative performance over the period 1997-2000. Introducing this lag is a way to account for the time required to transform innovative capabilities into concrete innovation. Descriptive statistics of the whole dataset are provided in appendix 3.

\section{Results}

As patents are measured on a four-year period (19972000), and as only fractions of patents are attributed to regions in case of multi-region patents, the dependent variables finally consists in a quasi continuum of values, what justifies the use of an OLS estimation procedure. Table I summarizes the results of the models tested on the whole sample.

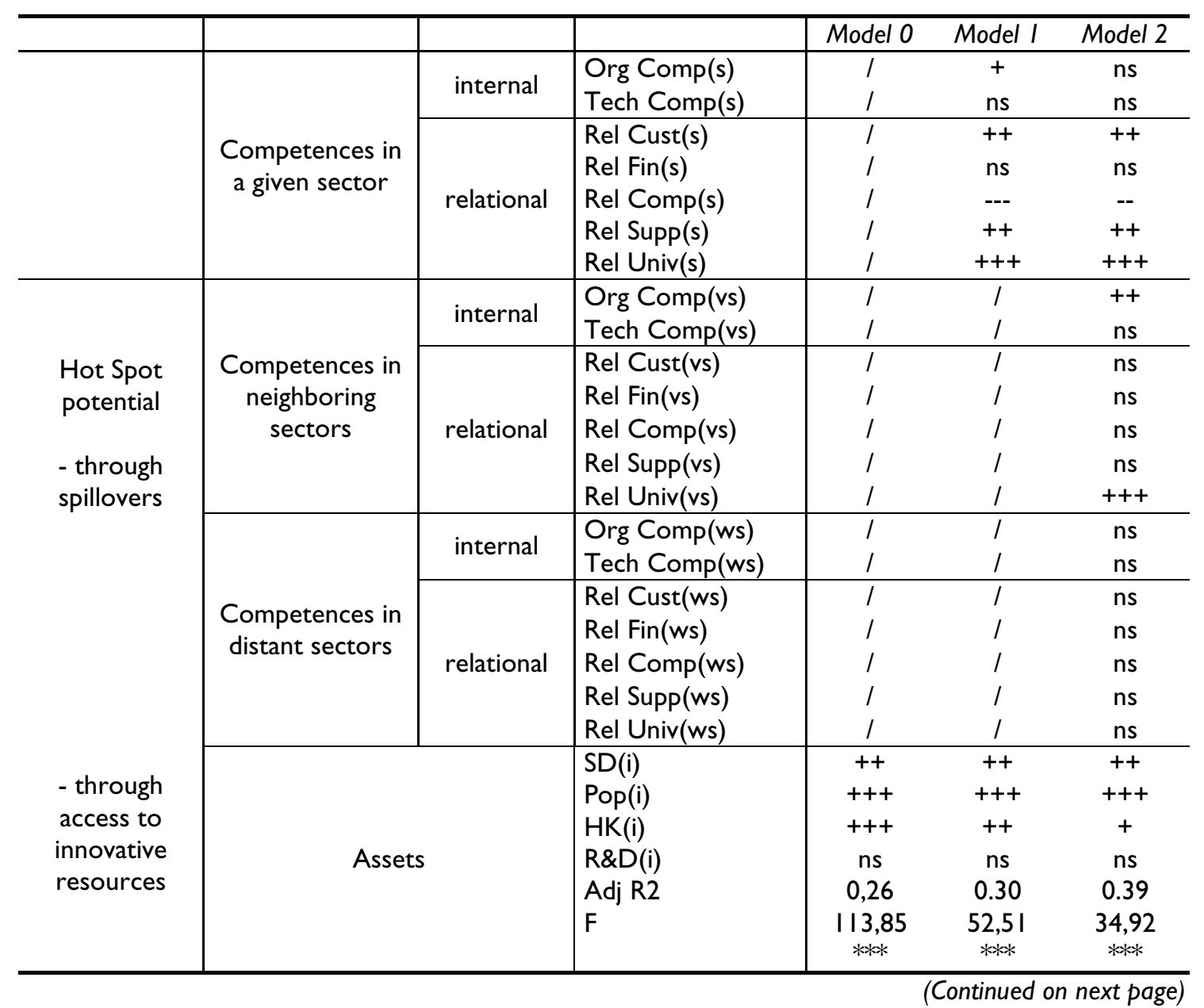


(Continued from previous page)

Data source: Sessi(1997), EPO (1997-2000)

ns : not statistically significant ;

+++ (---), positive (negative) estimated coefficient with I\% statistical significance,

$++(--)$ positive (negative) estimated coefficient with $5 \%$ statistical significance,

$+(-)$ positive (negative) estimated coefficient with $10 \%$ statistical significance.

Table I: Determinants of innovative performance: econometric results (1316 observations)

A first point to be noticed is the differentiated impact of each category of competences, confirming the need in future research to rely more systematically on multiple networks models. Going more into depth, model I shows that relational competences with economic partners (customers, suppliers or universities) are crucial in the innovative race, what confirms the Open innovation intuitions: external networking activities lead to higher innovative levels than pure in-house development of innovative competences. On the contrary, developing competitive watch seems to slow down innovation (as testified by the negative sign associated to Relcomp(s)). This result might be explained by the fact that a firm which invests time and energy to scan its competitors' activities and research projects- might discover that its competitors are going to apply for a patent on a given technology. As this patent would allow the competitors to pre-empt the technology and maybe the market, the firm might be dissuaded to engage itself in patenting the same technology.

Looking at the potential beneficial effects of hot spots, the empirical findings also presents universities as an engine of innovation for regional firms: indeed the coefficient associated to Scientific Density suggests that being located in the vicinity of an active university is beneficial, whatever the capabilities of regional firms to run interactions with those public institutions. The estimations also testify that increasing the human capital level available in a territory is still a good way to improve innovation in a region (see the positive and significant coefficient of the variable HK), probably since that allows a more rapid absorption of external knowledge. Nevertheless, this impact decreases when explanatory variables on competences are included in the model (see the decreasing coefficient and significance of the variable $\mathrm{HK}$ in model I vs in model 0 ) what suggests that most of existing studies on the topic (including indicators of human capital stock but neglecting to account for competences) overestimate the beneficial impact of hot spot locations on local innovation.

Model 2 provides another important result: the regional intensity of innovation of a given industry is positively influenced by the competences mastered by technological neighbors. Hence for instance, the significance of the variables Reluniv(vs) proves that networking with universities generates not only direct positive impacts on regional innovation but also leads to indirect beneficial effects on proximate technological activities. However, competences mastered by technologically-distant sectors (ws) within the region, do not influence the level of innovation in sector (s). In other words, the characteristics of the a firm's location in terms of access to innovative resources and of industrial structure (whether the firms evolves in a more or less specialized region) do matter: there exists some hot spots for establishing innovative activities.

These preliminary results have to be investigated in more depth, so as to check for industrial specificities. This is the aim of the second round of estimations which try and identify, industry by industry, the nature of the networking competences that are required for innovation, and the impact of competences of neighboring industries on regional innovation. The competences of non-neighboring industries are skipped from the analysis at the industrial level, as the results on the whole sample show that they do not have any significant impact. Table 2 summarizes the significant effects of this second round of estimations. 


\begin{tabular}{|c|c|c|}
\hline Sectors & $\begin{array}{l}\text { Effects of competences mastered } \\
\text { within the sector and the region }\end{array}$ & $\begin{array}{l}\text { Effects of regional competences } \\
\text { in neighboring sectors }\end{array}$ \\
\hline Clothing and leather & Fin $(+)$ & $\begin{array}{c}\text { Org }(+), \operatorname{Comp}(+), \operatorname{Tech}(-) \\
\text { Cust }(-)\end{array}$ \\
\hline Printing and publishing & Comp(-) & Comp $(+)$ \\
\hline Pharmaceuticals and cosmetics & Supp $(+)$ & l \\
\hline Household appliances & 1 & Univ $(+)$ \\
\hline Car industry & I & $\operatorname{Org}(+), \operatorname{Tech}(-), \operatorname{Comp}(-)$ \\
\hline Shipbuilding, aeronautics and railway & l & 1 \\
\hline Mechanical equipments & l & $\operatorname{Comp}(+), \operatorname{Univ}(+)$ \\
\hline Electric and electronic equipments & I & i \\
\hline Mineral products & $\operatorname{Comp}(+)$ & l \\
\hline Textile & l & Comp $(+)$ \\
\hline Wood and paper & l & i \\
\hline Chemical industry and plastics & Comp $(+)$ & Univ $(+)$ \\
\hline Metallurgy & l & 1 \\
\hline Electric and electronic compounds & Supp $(+)$ & $\operatorname{Supp}(-), \operatorname{Univ}(+), \operatorname{Fin}(+)$ \\
\hline
\end{tabular}

Table 2: Econometric results per industry: sum-up of significant effects at $5 \%$

The first point to focus on is that 6 industrial sectors show a positive link between the level of competences in their sector and the regional innovative output. Within this group of sectors, the competences to be held in order to be innovative vary. Nevertheless, if different, relational competences (whatever the partners) are the only competences required to improve innovation (indeed, technical and organizational competences never prove significant).

The absence of a simple one to one relationship between innovativeness and openness at the industry level may be explained by the complexity of the various technological knowledge bases. For instance, confirming Laursen and Salter (2006), table 2 shows that "low tech sectors have a low level of external search breadth". Put differently, the number of external sources or search channels that firms rely upon in their innovative activities is rather limited. Indeed firms active in the wood and paper industry, in textile or metallurgy do not rely on external partners at all for developing innovative ideas, whereas innovation in the clothing and leather industry might benefit from privileged relationships focused on financers. This observation suggests that the benefits of openness in those sectors might be counterbalanced by a prohibitive cost of search (which can be overcome by developing strong partnerships with financers). Another explanation might be that in those industries, technologies are rather "elementary" and therefore do not require access to external and complementary skills to be improved.

Regarding more high tech industries, they mainly increase their innovativeness by investing in relational competences towards suppliers (as it is the case in the pharmaceuticals and in electric and electronic compounds for instance). In other words, firms in those sectors adopt business models dedicated to take advantage of the creativity of their suppliers. This result sounds a bit in contradiction with the paper by Johnsen, et al. (2006) where the authors conclude that relying on customers/suppliers sound less important in the innovation process at stake in fluid and emerging contexts than in mature contexts. In the present empirical analysis, high tech sectors, which are rather rapidly moving industries, improve their innovative performance through relations with suppliers. This difference might be explained by the very specific nature of the suppliers of those high tech firms, as most of their suppliers are actually research labs (in biology for pharmaceuticals and in physics or chemicals for electric and electronic compounds).

A second point to highlight is that industries which do not rely on their own relational competences can benefit from the competences mastered by their technological neighbors. Indeed, the innovation performance of 8 industries out of the 14 of the sample is positively correlated with the networking competences of their technological neighbors. Hence, some competences (again 
the relational ones) have an indirect impact on innovation (what is more specifically the case in medium tech industries such as household appliances, car industry or mechanicals). More precisely, relations with universities (respectively relations with competitors) developed by neighbors are always (respectively generally) associated with a positive coefficient. Put differently, technological and scientific watch in a given industry have a positive impact on the innovativeness of neighboring industries probably because of a share of common knowledge bases between technological neighbors. This finding suggests that, at the firm level, establishing in hot spots might be stimulating, in the case those hot spots are not mono-industrial, that is when such indirect and positive inter-technological effects are not reduced or even annihilated by a too strict industrial specialization.

\section{Implications for research and managers}

This investigation of the determinants of innovation highlights the pregnant role of relational competences and thus the significant impact of capacities to engage in networking strategies. Actually, building relational competences can create both direct and indirect positive effects on innovation. Indeed some specific relational competences generate intra-regional spillovers among technological neighbors (as soon as regional actors are not too technologically different). Those indirect and positive effects can also be viewed as a motivation for firms looking for innovation to establish in industrially diversified region in priority.

If networking competences appear of primary importance in almost all industries, each industry however innovates thanks to different mechanisms of interactions: a first group of industries continues to innovate mainly "in house", whereas other sectors of activities ground their innovation on strong relational competences and partnerships, and industries of a third group mainly innovate thanks to inter-industrial spillovers generated by the relational competences of their technological neighbors. Those results confirm Tidd (2007)'s conclusions according to which "in some sectors, innovation is still and will remain largely internalized in large firms... whereas in others... [innovation requires a] delicate balancing of internal and external sources of innovation". In a word, French manufacturing firms adopt different business models (more or less cooperative) to organize technological innovation, depending on their sector of activity.

Third, this contribution provides evidence that investing in the building of networks of actors is more efficient to increase innovativeness than selecting a location providing highly qualified manpower, top universities, and hosting numerous and agglomerated creative firms. Indeed, networking strategies of local firms de-multiply the beneficial effects of innovative resources available on a given territory. Finally, relying on knowledge producers active in one's vicinity is a strategy of limited effect as compared to investing time and money to develop linkages with selected partners. In a word, establishing in hot spots can be an innovative solution but of less efficiency than engaging in active (but selective) networking activity.

If this first study identifies the type of partnering competences firms should develop in order to innovate, the next step of this research would consist in focusing on the characteristics of the "ideal" partners. Indeed, mastering relational competences in only a precondition for innovation. To transform these abilities into effective relationships and fruitful exchanges, firms should select the appropriate partner(s): should they develop collaborations with a precise number of actors? of a specific size? playing a specific role in the business network? And once the partners have been selected, firms should also think about ways to ensure effective and multilateral knowledge exchanges during their partnerships. Further research would tackle those questions by switching from the internal analysis of relational competences to the analysis of the potential partners and their respective worth.

As manager need to concentrate their energy, effort and mindfulness on a limited number of issues in order to achieve successful strategic performance (Ocasio, 1997), this paper also provides interesting conclusions in terms of allocation of managerial attention. Indeed, developing internal innovation capabilities does not seem to be a sufficient condition to gain and sustain competitive advantage any longer. Managers should prioritize the development of relational competences within their teams. But external relationships need to be managed effectively and efficiently. Indeed as the strategies to tap into external innovation sources are sector-specific, managers should concentrate on developing only selective partnering competences involving only some specific parts of their 
organization (R\&D, supply, marketing or accountancy and finance, depending on the industry at stake). This capacity to select the appropriate relational competences to be encouraged becomes a critical managerial task to remain active in the innovative race. At the same time, managers should not forget that a minimum of internal technological competence is however still required to be able to absorb and take advantage of external knowledge. Therefore they have to be careful that a management too excessively (and exclusively) oriented towards external partners would not become damageable for the innovative performance of their firms.

Moreover encouraging this new relational behavior by adopting some transversal (inter-organizational) management techniques and investing less time in stimulating internal creativity, might raise new managerial problems requiring new abilities. Indeed, exploitation and exploration innovation do not rely on similar managerial competences (Pandey and Sharma, 2009). Hence, negotiation skills, non-hierarchical management capacities or abilities to delineate an appropriate knowledge sharing policy between partners are probably the key competences to be developed to make open innovation effective. The new challenge for managers finally lies in developing new incitation mechanisms so that all the partners, even if not coordinated through a hierarchical authority but only interacting according to contractual agreements, would agree to exchange knowledge and ideas with one another, rather than free-ride.

\section{References}

ACS, Z. Anselin, L. Varga, A. (2002). Patents and Innovation Counts as Measures of Regional Production of New Knowledge. Research Policy, 31, 1069-1085.

AUTANT-BERNARD, C. (200I). Science and knowledge flows: evidence from the French case, Research Policy, 30, Pp. 1069-1078.

BELL, G. (2005). Clusters, networks and firm innovativeness. Strategic Management Journal, 26(3), 287295.

BRESCHI, S., Lissoni, F., Malerba, F., (2003). Knowledge relatedness in firm technological diversification. Research Policy, 32, I, 69-87.
CHESBROUGH, H. (2003). Open Innovation, Harvard Business School Press, Boston, Mass.

COOKE, P., Heidenreich, M., Braczyk, H-J. (2004). Regional Innovation Systems: The role of governance in a globalized world, 2nd edition. Routledge, London; New York:.

DE JONG, J., Vanhaverbeke, W, Van de Vrande, V., (2007) Open innovation in SMEs: tends, motives and management challenges, EURAM 2007.

ENGELSMAN, E.C., van Raan, A.F.J. (1992). A patent-based cartography of technology. Research Policy, 23, I-26.

FRANÇOIS, J.P. Goux, D. Guellec, D. Kabla, I. Temple, P. (1999). Décrire les compétences pour l'innovation. Une proposition d'enquète. In Foray, D. Mairesse, J. (Eds.), Innovations et Performances: Approches Interdisciplinaires, ed. EHESS, pp. 283-305.

FRITSCH, M., (2004). R\&D co-operation and the efficiency of regional innovation activities. Cambridge Journal of Economics, 28(6), 829-846.

FRITSCH, M. Franke, G. (2004). Innovation, regional knowledge spillovers and R\&D cooperation. Research policy, 33, pp 245-255.

GEMÜNDEN HG, Ritter, T, Heydebreck P. (1996). Network configuration and innovation success: an empirical analysis in German high tech industries. international journal of research in Marketing, I3(5), 449-462.

GRILICHES, Z. (1979). Issues in assessing the contribution of R\&D to productivity growth, Bell Journal of Economics, 10: $92-116$.

GRILICHES, Z. (1990). Patent Statistics As Economic Indicators: A Survey. Journal of Economic Literature, 28, 166|-707.

JOHNSEN T., Phillips W., Caldwell N., Lewis, M. (2006). Centrality of customer and supplier interaction in innovation. Journal of Business Research, 59, 671-678.

LAURSEN, K., Salter, A. (2006). Open for innovation: the role of openness in explaining innovation performance among UK manufacturing firms. Strategic Management Journal, 27, $|3|-\mid 50$.

ISSN: 07I8-2724. (http://www.jotmi.org)

Journal of Technology Management \& Innovation (c) Universidad Alberto Hurtado, Facultad de Economía y Negocios 
LOVE, J., Ropper, S. (200I). Location and network effects on innovation success: evidence for UK, German and Irish manufacturing plants. Research Policy, 30, pp. 643-662.

MAILLAT, D. Kebir, L. (1999). Learning region et systemes territoriaux de production. Revue d'Economie Regionale et Urbaine, Volume 0, Issue 3, 1999, pp. 429-448.

MARSHALL, A, (1890). Principles of Economics. Mac Millan, London.

OCASIO, W. (1997) Towards an Attention-Based View of the Firm. Strategic Management Journal, Vol. I8, pp. 187-206

OERLEMANS, L., Meeus, M., Boekema, F. (1998). Do networks matter for innovation? The usefulness of the economic network approach in analysing innovation. Tijdschrift voor Economische en Sociale Geografie, 89, 298-309.

PAVITT, K. (1984). Sectoral patterns of technical change: towards a taxonomy and a theory. Research Policy 13, PP. 343-373.

PANDEY, S., Sharma, RRK, (2009). Organizational factors for exploration and exploitation. Journal of Technology Management and Innovation, 4(I), 48-58.

PRAHALAD CK, Hamel, G. (1990). The core competence of the corporation. Harvard Business Review, 68(3), 79-9l.

RITTER, T., Gemünden, H.G. (2003). Network competence: its impact on innovation success and its antecedents. Journal of Business Research, 56, 745-755.

RONDÉ, P., Hussler, C. (2005). Innovation in regions: what does really matter? Research Policy, 34, 8, II 50-72.

TIDD, J., (2007), Challenges of innovation, globalization and development. ISMOT 2007. 


\section{Appendix}

\section{Appendix I: Aggregate Competences}

\begin{tabular}{|c|c|c|c|}
\hline $\begin{array}{l}\text { Innovative } \\
\text { practice }\end{array}$ & $\begin{array}{l}\text { Related } \\
\text { competences }\end{array}$ & Description & Examples \\
\hline \multirow{2}{*}{$\begin{array}{l}\text { In house } \\
\text { innovation }\end{array}$} & $\begin{array}{l}\text { Organizational } \\
\text { competences } \\
\qquad(\mathrm{k}=\mathrm{l})\end{array}$ & $\begin{array}{l}\text { competences linked to human } \\
\text { resources organization and } \\
\text { transversal knowledge generation - } \\
\text { ability to focus and organize the firms } \\
\text { around innovative projects }\end{array}$ & $\begin{array}{l}\text { Joint work to innovate } \\
\text { Mobility between the services } \\
\text { Incentives to formulate new ideas } \\
\text { Identification of the persons holding } \\
\text { strategic know-how }\end{array}$ \\
\hline & $\begin{array}{c}\text { Technical } \\
\text { competences } \\
(\mathrm{k}=2)\end{array}$ & $\begin{array}{l}\text { competences in managing and } \\
\text { mastering in- house R\&D and } \\
\text { technologies but also in forecasting } \\
\text { technological evolutions }\end{array}$ & $\begin{array}{l}\text { Carrying out a technological assessment of } \\
\text { the company } \\
\text { Test of innovating products and processes } \\
\text { in their operational contexts } \\
\text { Analyzing flaws and breakdowns of the } \\
\text { new processes } \\
\text { R\&D }\end{array}$ \\
\hline \multirow{5}{*}{$\begin{array}{c}\text { Open } \\
\text { innovation }\end{array}$} & $\begin{array}{l}\text { Relations with } \\
\text { universities } \\
\qquad(\mathrm{k}=3)\end{array}$ & $\begin{array}{l}\text { collaborations with public research } \\
\text { institutions - hiring of scientists }\end{array}$ & $\begin{array}{l}\text { R\&D partnerships with public } \\
\text { organizations } \\
\text { Recruitment of employees of high } \\
\text { scientific qualification to innovate }\end{array}$ \\
\hline & $\begin{array}{l}\text { Relations with } \\
\text { competitors } \\
\qquad(\mathrm{k}=4)\end{array}$ & $\begin{array}{c}\text { ability to watch up its competitors } \\
\text { but also to co-operate with other } \\
\text { competing companies }\end{array}$ & $\begin{array}{l}\text { R\&D alliances with other companies } \\
\text { Using external inventions (patents, } \\
\text { licenses) } \\
\text { Knowing competitors technologies }\end{array}$ \\
\hline & $\begin{array}{l}\text { Interactions } \\
\text { with suppliers } \\
\quad(\mathrm{k}=6)\end{array}$ & $\begin{array}{c}\text { capability to choose and work with } \\
\text { (and benefit from the knowledge of) } \\
\text { highly innovative suppliers }\end{array}$ & $\begin{array}{l}\text { Fast adoption of the technologically new } \\
\text { equipment } \\
\text { Fast adoption of the technologically new } \\
\text { supplies } \\
\text { Subcontracting or acquisition of R\&D } \\
\text { Subcontractor of highly technological } \\
\text { components }\end{array}$ \\
\hline & $\begin{array}{l}\text { Collaborations } \\
\text { with customers } \\
\qquad(\mathrm{k}=5)\end{array}$ & $\begin{array}{l}\text { capacity to take the consumers' } \\
\text { needs into consideration and to } \\
\text { exchange knowledge and products } \\
\text { with them }\end{array}$ & $\begin{array}{l}\text { Collecting customers reactions at after- } \\
\text { sales services or retailers } \\
\text { Using the product as a source of } \\
\text { information about the customers } \\
\text { satisfaction } \\
\text { Testing the ultimate consumer } \\
\text { Identifying new behaviors and pioneering } \\
\text { consumers }\end{array}$ \\
\hline & $\begin{array}{c}\text { Financial } \\
\text { competences } \\
\quad(k=7)\end{array}$ & $\begin{array}{c}\text { competences to cope with innovation } \\
\text { costs thanks to various external } \\
\text { financial supports }\end{array}$ & $\begin{array}{l}\text { Knowing the private and public modes of } \\
\text { financing innovation } \\
\text { Communication strategy towards } \\
\text { potential financial partners of innovation }\end{array}$ \\
\hline
\end{tabular}




\section{Appendix 2: Technological Neighborhood: Results}

\begin{tabular}{|c|c|c|}
\hline $\begin{array}{c}\text { Code } \\
\text { sector }\end{array}$ & Industrial sectors & $\begin{array}{c}\text { Technological } \\
\text { neighboring sectors } \\
(\mathrm{v}(\mathrm{s}))\end{array}$ \\
\hline $\mathrm{I}$ & Clothing and leather & $2,4,7$ \\
\hline 2 & Printing and publishing & $\mathrm{I}, 4,7,8, \mathrm{II}$ \\
\hline 3 & Pharmacy & 8,12 \\
\hline 4 & Household appliances & $\mathrm{I}, 2,7,8,10,14$ \\
\hline 5 & Car Industry & $6,7,1 \mathrm{I}, 12$ \\
\hline 6 & Other transport industries & $5,7,1 \mathrm{II}$ \\
\hline 7 & Mechanical equipments & $\mathrm{I}, 2,4,5,6,1 \mathrm{I}, 12,13$ \\
\hline 8 & $\begin{array}{c}\text { Electric and electronic } \\
\text { equipments }\end{array}$ & $2,3,4$ \\
\hline 9 & Mineral products & $1 \mathrm{II}$ \\
\hline 10 & Textile & $4,1 \mathrm{I}, 12$ \\
\hline $1 \mathrm{I}$ & Wood and paper & $2,5,6,7,9,10,12$ \\
\hline 12 & Chemistry & $3,5,7,10,1 \mathrm{I}$ \\
\hline 13 & Metallurgy & $7,1 \mathrm{I}, 12$ \\
\hline 14 & $\begin{array}{c}\text { Electric and electronic } \\
\text { compounds }\end{array}$ & 4 \\
\hline
\end{tabular}

The set $\mathrm{w}(\mathrm{s})$ is constituted by the sectors that are not included in the $\mathrm{v}(\mathrm{s})$ set.

\section{Appendix 3: Descriptive Statistics}

\begin{tabular}{|c|c|c|c|c|c|}
\hline Variables & & Max & Min & Mean & Std D. \\
\hline \multirow[t]{2}{*}{ Pat (is) } & $\begin{array}{l}\text { Decimal number of patent applications in region i and sector } \\
\text { s during the } 1997-2000 \text { period }\end{array}$ & 610,9 & 0 & 14,6 & 44,1 \\
\hline & Competences mastered in sector $\mathbf{s}$ & & & & \\
\hline Org (is) & Number of organizational competences & 1446 & 0 & 53,8 & 106,5 \\
\hline Tech (is) & Number of technical competences & 590 & 0 & 24,5 & 46,4 \\
\hline R. Cust(is) & Number of relational competences & 418 & 0 & 14,4 & 30,5 \\
\hline R. Fin(is) & Number of relational competences with financers & 114 & 0 & 5,7 & 11,2 \\
\hline R. Comp(is) & Number of relational competences with competitors & 544 & 0 & 16,9 & 35,6 \\
\hline R. Supp(is) & Number of relational competences with suppliers & 157 & 0 & 6,2 & 12,8 \\
\hline \multirow[t]{2}{*}{ R. Univ(is) } & Number of relational competences with university & 94 & 0 & 2,1 & 5,8 \\
\hline & Competences mastered by technological neighbors & & & & \\
\hline Org (vs) & Number of organizational competences & 2609 & 0 & 270,6 & 340,7 \\
\hline Tech (vs) & Number of technical competences & 1103 & 0 & 123,9 & 153,6 \\
\hline R. Cust(vs) & Number of relational competences with customers & 732 & 0 & 72,6 & 95,1 \\
\hline R. Fin(vs) & Number of relational competences with financers & 223 & 0 & 28,9 & 36,1 \\
\hline R. Comp(vs) & Number of relational competences with competitors & 959 & 0 & 85,9 & $1 \mid 5,2$ \\
\hline R. Supp(vs) & Number of relational competences with suppliers & 276 & 0 & 31,2 & $4 I, 5$ \\
\hline \multirow[t]{2}{*}{ R. Univ(vs) } & Number of relational competences with university & 144 & 0 & 10,4 & 18 \\
\hline & Competences mastered in more distant technologies & & & & \\
\hline Org (ws) & Number of organizational competences & 5189 & 0 & 304,4 & 542,1 \\
\hline Tech (ws) & Number of technical competences & 2287 & 0 & 138,5 & 238,1 \\
\hline R. Cust(ws) & Number of relational competences with customers & 1628 & 0 & 84,5 & 162 \\
\hline R. Fin(ws) & Number of relational competences with financers & 534 & 0 & 32,5 & 57,1 \\
\hline
\end{tabular}




\begin{tabular}{|c|c|c|c|c|c|}
\hline R. Comp(ws) & Number of relational competences with competitors & 1900 & 0 & 98,6 & 186,7 \\
\hline R. Supp(ws) & Number of relational competences with suppliers & 679 & 0 & 35,9 & 67,5 \\
\hline \multirow[t]{2}{*}{ R. Univ(ws) } & Number of relational competences with university & 323 & 0 & 13 & 30,1 \\
\hline & Regional assets & & & & \\
\hline SD(i) & $\begin{array}{l}\text { Dummy variable taking the value I if the regional scientific } \\
\text { intensity is above the French average }\end{array}$ & $\mathrm{I}$ & 0 & 0,2 & 0,4 \\
\hline POP(i) & Population of the region in thousands inhabitants & 2555 & 74 & 480 & 2.07 \\
\hline $\mathrm{HK}(\mathrm{i})$ & $\begin{array}{l}\text { Number of researchers in the private sector per } 10000 \\
\text { inhabitants }\end{array}$ & 31,7 & 2,2 & 9,25 & 7,63 \\
\hline$R \& D(i)$ & Proportion of regional budget devoted to RD activities & 4,3 & 0,4 & 2,42 & 0,99 \\
\hline
\end{tabular}

